\title{
Study on diversified cultivation orientation and pattern of optoelectronic major undergraduates
}

Zhiying Liu

Zhiying Liu, "Study on diversified cultivation orientation and pattern of optoelectronic major undergraduates," Proc. SPIE 10452, 14th Conference on Education and Training in Optics and Photonics: ETOP 2017, 104523W (16 August 2017); doi: 10.1117/12.2264884

SPIE Event: 14th Conference on Education and Training in Optics and Photonics, ETOP 2017, 2017, Hangzhou, China 


\title{
Study on dive rsified cultivation orientation and pattern of opto- electronic major undergraduates
}

\author{
Zhiying Liu $^{* a}$ \\ ${ }^{a}$ School of opto-electronic engineering, Changchun University of Science and Technology, No 7089 \\ Weixing Road,Changchun, Jilin, CHINA 130022
}

\begin{abstract}
To improve the research quality preparation for graduate study and looking for job competition ability of undergraduates students, the education orientation objective need to be explicit. Universities need develop undergraduates' cultivation plan according to students' classification. Based on analysis of students export characteristic, there will be corresponding cultivation plan. Keep tracking study during the cultivation plan implantation process, the Curriculum system and related manage documents are revised corresponding to exist problems. There are mainly three kinds of undergraduates' career direction plan for opto-electronic major undergraduates. In addition to the vast majority university graduates opting for direct employment, nearly onethird of university students choose to take part in the postgraduateentrance exams and other further e ducation abroad, and also one-tenth choose their own businesses, university chooses are diversified. The exports are further studying as graduates, working and study abroad. Because national defense students are also recruited, the cultivation plan will be diversified to four types. For students, who go to work directly after graduation, the "Excellence engineers plan" is implemented to enhance their practice ability. For students, who will study further as graduate student, the scientific innovation research ability cultivation is paid more attention to make good foundation for their subsequent development. For students, who want to study abroad after graduation, the bilingual teaching method is introduced, and the English environment is built. We asked foreign professionals to give lectures for students. The knowledge range is extending, and the exchange and cooperation chance is provided at the same time. And the cultivation plan is revised during docking with Universities abroad. For national defense students, combat training and other defense theory courses are added to make them familiar with force knowledge. And with national defense students' excellence engineer plan, more army practice chance is provided. The students can integrate into army life much faster. The advantages of national defense students are much more highlighted. The graduates can serve motherland better than before. It is shown from the practice process that the revised cultivation plan is suitable for diversified undergraduates. And the education result is improved in a large amount consequently.
\end{abstract}

Keywords: Opto-electronic major, Diversified, Career direction, Cultivation plan

\section{INTRODUCTION}

The major of opto-electronic information science and engineering originated from optical instrument major, which started since 1950s. There are several name changes history, from optical technology and opto-electronic instrument on 1993 to information engineering and optical information science and technology on $1998^{[1-3]}$. It is shown from major history that the modern education is developing with the times. And it is also shown that the development of science technology and subject major development. The advantages and tradition of optical instrument major is forward by optoelectronic engineering major. And with electronics and information contents, the major becomes an intersection major ${ }^{[4]}$.

14th Conference on Education and Training in Optics and Photonics: ETOP 2017, edited by Xu Liu,

Xi-Cheng Zhang, Proc. of SPIE Vol. 10452, 104523W · C 2017 ICO, IEEE, OSA, SPIE

CCC code: $0277-786 X / 17 / \$ 18 \cdot$ doi: $10.1117 / 12.2264884$ 
With development of opto-electronic information industry, the demands of opto-electronic engineering technology talents are increasing year by year. It should be paid more attention that improvement of the innovation and construction of modern university education further. And consequently, much higher quality opto-electronic information technology talents are acquired ${ }^{[34]}$.

\section{MULTI-CULTIVATION CLASSIFICATION}

The undergraduate students, who major in opto-electronic information engineering, should have modern science idea, foundation of well-knit theoretic, broad knowledge field, powerful innovation ability ${ }^{[4]}$.

The multi-level and diversity practical teaching system and cultivation model are built. It aims on students' innovation application ability.

\subsection{Classification of the opto-electronic major orientation target}

The talents of opto-electronic major are generally separated as three classes, study further, go to work, and study aboard. The cultivation plan needs to be adjusted according to three classifications. We have national defense students, their cultivation plan needs adjustment too.

\subsection{Adjustment of opto-electronic major classification cultivation plan}

Cultivation plan Adjustment of "DAHENG" talents in this class, there are many students choose to have post graduate students entrance exam every year.The top ranking 30 students are selected to "DAHENG" class. The cultivation plan for this class aims on better cycle and inspiring scheme. It makes students have study initiative. Every student in this class has a tutor to direct them on major orientation and research experience. During the co-research with tutor, the students are guided to participate tutor's research work. They will have good preparation for graduates study in advance. And the innovation research ability is stored too. The ability of thin king and solve problem is improved.

In addition, research project, subject competition, innovation project, these practical steps are another important path to innovation engineering talents. The engineering quality, engineering practice and innovation ability are acquired. To get better result, the self learning hours is increased.

\subsection{Adjustment for cul tivation plan of general class}

In the general class, there will be 20\%-30\% want to study further as post graduates. In these talents, most of them went to work when they graduated. Because they will work for national industry or Personal Corporation, the requirements on talents we should know it clearly.

Start from profit to undergraduates finding job, the excellent engineer cultivation plan is proposed ${ }^{[5]}$. It is different from the population engineering education that the excellent engineering is determined by university and corporations. The lecture system and teaching contents are co-constructed by university and corporation. The corporation takes part in the cultivation process of undergraduate students. The model is " $3+1$ ". The beginning three years study in university, and go to corporation to have engineering practice during the last year. The corporation engineering practice changed the traditional university primary; the corporation participated in the undergraduates' cultivation whole process. They consider the students as their faculty. During the development and production process, the students can familiar with corporation background and learn to comply with corporation rules.

During practice in corporation, they are instructed by teachers from university and corporation. The corporation engineering technology faculty is the main force, rely on advantages of characteristic subject, rely on fundamentals of long period cooperation, the functions of practice and exercise foundation are extended. Corporation is the important loader of innovation talents cultivation. The talents are customized, and it becomes effective tunnel for transfer human resource for corporation. The students will fit to the job as soon as possible with exercise of innovation ability, practical ability and team cooperation.

To extend university exercise foundation, university have proposal with several Changchun noble corporations. We provide customized engineering talents for corporations.

\subsection{Adjustment of international talent cultivation plan}

With development of economic globalization, the international talents are demanded urgently ${ }^{[6]}$. Nowadays, the international class emerged in many universities. The factors are education cost, education amount, education quality. In this class, most of the profession courses are taught in English. The courses are adjusted for convenience of study aboard. Talents exported from this class are compatible when they find job. Except that, there are many noble professors from aboard give lectures to the students in this class. It is exciting that one of the students got recommend letter to MIT 
University, which shows that the mutual communication is well and the promotion function of international talent class is effective.

\subsection{Cultivation plan adjustment of national defense students}

After exchange idea with national defense students' cultivation office, the cultivation demands are much clearer than before. The military and policy education exercise contents are add in. besides that, the military theory and fighting foundation and exercise foundation are added too. Because most of the national defense students will join the information modern opto-electronic instrument and device, the information optics knowledge system is strengthened. The production practice is substituted by army exercise, which increased the exercise and study time and chance.

The national defense students make utilized the off-class hours, weekends and winter and summer holidays to do military exercise and improve the military quality and practical ability. The national defense students have central train ing during summer holidays. Through this step, the military quality of national defense students is improved. They have primary impression of military life, and have the primary ability fit to army position. Every person can have his advantages work as large amount as possible. Besides that, combined with excellent engineering project of army, the excellent national defense students are selected to have one year training in the army.

The cultivation target of national defense excellent talent is clear. With orientation of information technique army demand, with background of information and communication engineering military application, and with main line of engineering technique, the theory foundation is strengthened and the military quality training is highlighted. The military engineering practical ability and officer basic quality are cultivated.

\section{CONCLUSIONS}

With adjustment of cultivation plan, and with classification of talents, the outcomes are following. For excellent exercise engineering plan, the improvement of practical ability and major cognition ensure students compatible ability under higher work hunting pressure. The adjustment of international talents and Da-heng class cultivation mode give students research innovation ability. They got better feedback during their graduate entrance interview. We keep recording that we have talents export to top rank university, which is noble in this major. The knowledge and practical military ability are improved at the same time. The scores are getting higher, and the active learning interest is stronger. They begin to think and learn from heart.

\section{REFERENCES}

[1] YU Dao-yin,CAI Huai-yu,GE Bao-zhen."Practice in constructing the specialty of photoelectric information Engineering, " $\mathrm{O}$ PTICAL TECHNIQUE, Papers Vol (33):293-294(2007).

[2] ZHANG Shun-ru,DENG Xiao-peng."Research on the Relations between Course Design and Professions of the Photoelectric Information Science And Engineering Specialty in Local Universities,"Journal of HUAIHUA University , Papers 35 (5) :8485(2016) .

[3] JIA Guang-han."Photoelectric information engineering professionals develop new ideas, "Journal of Changchun Education Institute, Papers 31(24):106-107(2015).

[4] ZHANG Hai-min, SHANG Ke-ke, GAO Gui. "Exploration and practice in professional training of local university for the major of optoelectronic information science and en gineering,". Phy sics and Engineering, Papers 25(2):89-92(2015).

[5] BIAN Jing-mei,SUN Ji-zhuang, ZHOU Chao."Teaching reform of en gineering management specialty based on excellent plan," Journal of Architectural Education in Institutions of Higher Learning, Papers 24(1):111-114(2015).

[6] Zhang Wei,Jia Hong-zhi,Zheng Ji-hong. "Reasearch on Curriculum Design of Optoelectronic En gineering Major in Running the International Cooperative Program,” Journal of University of Shan ghai for Science and Technology, Papers 38 (3):272-275 (2016).

*lzy @ cust.edu.cn; phone 86-0431-85582518; fax 86-0431-85582518; www.cust.edu.cn 